\title{
VICTIM PRECIPITATIONDALAM TINDAK PIDANA PENGHINAAN DAN PENCEMARAN NAMA BAIK DI MEDIA SOSIAL (Studi Kasus Terhadap Putusan Perkara Nomor 310/PID.SUS/2017/PN.IDM)
} Oleh: Ari Prakoso'

\begin{abstract}
Victim Precipation is a criminology science that studies how interactions between victims and perpetrators can contribute to criminal offenses. Victim Precipation is the attitude and condition of someone who will be a potential victim or attitude and condition that can trigger someone to commit a crime. The role of victims of crime, among others, relates to what is done by the victim, when something is done, where it is done. Between the victim and the perpetrator there is a functional relationship that results in the occurrence of a crime.

This study aims to analyze victim precipitation occurring in criminal acts of humiliation and defamation on social media in the jurisdiction of the Indramayu District Court and to analyze the reasons the judges did not use aspect victim precipitation in their decisions in criminal acts of humiliation and defamation on social media in the region law of the Indramayu District Court. This research was conducted using sociological legal research methods (socio-legal research). The legal materials collected will be comprehensively reviewed and analyzed deductively with systematic presentation.

The results of the study that the occurrence of victim precipitation occurs in criminal acts of humiliation and defamation on social media in Decision Number 310 / Pid.Sus / 2017 / PN.Idm because provocative victims are the influence of victims provoke a crime. In this case the judge does not consider the aspects of victim preciipation in his decision in the offense of insulting and defamation on social media in the Decision Number 310 / Pid.Sus / 2017 / PN.Idm for the weighting reason in the decision namely that the victim does not play an active role because of the alleged by the defendant there was not enough evidence and the judge decided only based on the evidence submitted by the public prosecutor.
\end{abstract}

Keywords: Victim Precipitation, Humiliation Crime, Defamation on Social Media.

\section{ABSTRAK}

Victim Precipation adalah bagian dari ilmu kriminologi yang mempelajari tentang bagaimana interaksi antara korban dan pelaku dapat berkontribusi pada pelanggaran pidana. Victim Precipation adalah sikap dan keadaan diri seseorang yang akan menjadi calon korban atau sikap dan keadaan yang dapat memicu seseorang untuk melakukan kejahatan. Peran korban kejahatan antara lain berhubungan dengan apa yang dilakukan oleh pihak korban, kapan dilakukannya sesuatu, dimana hal tersebut dilakukan. Antara korban dan pelaku terdapat hubungan yang fungsional yang mengakibatkan terjadinya suatu kejahatan.

Penelitian ini bertujuan untuk menganalisis victim precipitation terjadi dalam tindak pidana penghinaan dan pencemaran nama baik di media sosial di wilayah hukum Pengadilan Negeri Indramayu serta menganalisis alasan hakim tidak menggunakan aspek victim precipitation didalam putusannya dalam tindak pidana penghinaan dan pencemaran nama baik di media sosial di wilayah hukum Pengadilan Negeri Indramayu. Penelitian ini dilakukan dengan menggunakan metode penelitian hukum yuridis sosiologis (sosio-legal research). Bahan hukum yang terkumpul akan dikaji secara komprehenif dan dianalisa secara deduktif dengan penyajian yang sistematis.

Hasil penelitian dan pembahasan terjadinya victim precipitation terjadi dalam tindak pidana penghinaan dan pencemaran nama baik di media sosial dalam Putusan Nomor 310/Pid.Sus/2017/PN.Idm adalah karena adanya tindakan provokatif korban (provocative victim) yaitu adanya pengaruh korban yang memancing adanya sebuah kejahatan. Dalam hal ini hakim tidak mempertimbangkan aspek victim preciipation didalam putusannya dalam tindak pidana penghinaan dan pencemaran nama baik di media sosial dalam Putusan Nomor 310/Pid.Sus/2017/PN.Idm karena alasan pemberat dalam putusan yaitu bahwa korban tidak berperan aktif karena yang dituduhkan oleh terdakwa belum cukup bukti serta hakim memutus hanya berdasar bukti yang diajukan jaksa penuntut umum saja. 
Kata Kunci : Victim Precipitation, Tindak Pidana Penghinaan, dan Pencemaran Nama Baik di Media Sosial

\section{A. Pendahuluan}

Hukum merupakan sistem berarti bahwa hukum itu merupakan tatanan, merupakan suatu kesatuan yang utuh yang terdiri dari bagian-bagian atau unsur-unsur yang berkaitan erat satu sama lain. Dengan demikian sistem hukum adalah suatu kesatuan yang terdiri dari unsur-unsur yang mempunyai interaksi satu sama lain dan bekerja sama lain dan bekerja sama untuk mencpai tujuan kesatuan tersebut. Sistem hukum merupakan kesatuan unsurunsur (yaitu peraturan, penetapan) yang dipengaruhi oleh faktor-faktor kebudayaan, sosial, ekonomi, sejarah, dan sebagainya. Sebaliknya, sistem hukum mempengaruhi faktor-faktor di luar sistem hukum tersebut. Peraturan-peraturan hukum itu terbuka untuk penafsiran yang berbeda, olehkarena itu selalu terjadi perkembangan. ${ }^{2}$

Hukum pidana menempati posisi penting dalam seluruh sistem hukum dalam suatu negara. Meskipun masih dipertanyakan manfaatnya dalam menyususn tata masyarakat yang tertib dan damai, tetapi semakin penting dipelajari segi-seginya untuk menjunjung seluruh sistem kehidupan di dalam masyarakat. Praktik penegakan hukum seringkali diwarnai dengan hal-hal yang yang bertentangan dengan prinsip-prinsip tersebut. Misalnya penganiyayaan terhadap tersangka untuk mengejar pengakuan, intimidasi rekayasa perkara, pemerasan, pungutan liar dan sebagainya. Kemudian dari pihak korban juga merasakan diabaikan hak-haknya, antara lain dakwaan lemah, tuntutan ringan, tidak mengetahui perkembangan penanganan

2 Sudikno Mertokusumo. 2010. Mengenal Hukum. Yogyakarta: Penerbit Cahaya Atma Pustaka, hlm. 159-160. perkara, tidak menerima kompensasi dan tidak terpenuhinnya hak-hak yang lain. ${ }^{3}$

Pasca 1940-an berkembang ilmu viktimologi yang secara khusus memutuskan perhatian pada arti penting dan peranan korban dalam konteks dinamika berlangsungnya kejahatan, serta sebab akibat kejahatan. Hal ini sebagai implikasi studi kejahatan berupa reaksi terhadap pemikiran korban sebagai objek pasif. Terlihat dalam buku karya Von Henting yang berjudul Remarks on The Interaction of Perpetrator and Victim (1941), dan The Criminal and His Victim (1948). Istilah viktimologi sendiri baru muncul pada 1947 yang diperkenalkan oleh Benjamin Mendelsohn dengan artikelnya berjudul "New Bio-Psycho Social Horizon: Victimology" (1947). Dapat dikemukakan bahwa tulisan kedua tokoh ini merupakan awal bagi perkembangan viktimologi. Karya-karya dalam studi viktimologi ini memperoleh pengakuan bagi perhatian terhadap korban dengan Simposium Internasional I tentang Viktimologi pada tanggal 2-6 September 1973 di Yarusalem, hingga sampai Simposium kelima di Zagreb, Yugoslavia pada $1985{ }^{4}$

Pada tujuan Viktimologi yaitu, explain the causes for victimization, berkaitan dengan sebab terjadinya pengorbanan Zvonir Paul Sparovic berpendapat mengenai kajian sebab terjadinya pengorbanan awalnya merupakan kajian kriminologi dan merupakan embrio tujuan viktimologi dalam arti sempit yaitu untuk mengetahui bagaimana kontribusi korban

3 Bambang Waluyo. 2012. Viktimologi Perlindungan Korban dan Saksi. Jakarta: Penerbit Sinar Grafika, hIm.1-2.

${ }^{4}$ Maya Indah S. 2014. Perlindungan Korban Suatu Perspektif Viktimologi dan Kriminologi. Jakarta: Penerbit Kencana Prenadamedia Group, hlm. 7. 
dalam terjadinya tindak pidana. Kajian ini dikembangkan mulai awal tahun 1970 an. Pada awalnya pandangan kontribusi dalam terjadinya pengorbanan adalah hal yang tidak dapat diterima karena dalam terjadinya tindak pidana tidak diperhitungkan. Hal ini tidak terlepas dari pandangan kriminologi ortodok yang mengabaikan peranan korban dalam terjadinya tindak pidana. ${ }^{5}$

Bahwa kajian viktimologi perlu dipahami juga dalam realitas lebih luas tidak hanya dikaitkan dengan peranan korban dalam terjadinya kejahatan yang oleh para ahli kriminologi digunakan konsep Victim precipitation ataupun provokasi korban. Realitas sosial korban yang ada, bahwa si korban sama sekali tidak tahu bahwa dirinya menjadi korban di samping itu sangatlah diragukan apabila posisi korban yang demikian menjadikan adanya keragu-raguan terhadap kesalahan dari pelaku. ${ }^{6}$ Berdasarkan pengertian yang luas menurut konsep diatas maka dapat ditemukan konsep pertanggungjawaban terbagi antara korban dan pelaku karena kedua belah pihak mempunyai kadar kesalahan. Bahkan korban dapat lebih bersalah daripada pelaku karena korban melakukan provokasi terlebih dahulu.

Menurut Wolfgang, dalam kasus pembunuhan berdasarkan analisis terhadap studi statistik ditemukan bahwa satu korban di antara empat kasus pembunuhan ikut mempercepat pembunuhan tersebut. Kemudian Amir yang mengkaji kasus pemerkosaan menunjukan korban berpartisipasi dan

\footnotetext{
${ }^{5}$ Angkasa. 2017. Teori Viktimologi dalam kontek Tujuan Viktimologi. Simposium Revitalisasi Hukum Nasional dan Pelatihan Hukum Pidana dan Kriminologi ke-IV, Kupang. hIm. 1.

${ }^{6}$ Maya Indah S. Op.Cit., hlm.14.
}

mempercepat satu diantara beberapa kasus perkosaan. Hasil studi tersebut diperkuat oleh penelitian Meir dan Meite pada tahun 1993, hasil penelitian tersebut menunjukkan dalam kasus perkosaan tingkat victim precipitation (VP) mencapai sekitar 4-19 \% karena kelalaian korban. ${ }^{7}$

Dari penjelasan studi tersebut, terlihat bahwa peranan korban sangat berpengaruh dalam suatu terjadinya suatu tindak kejahatan pidana dilihat dari sudut kelengahan korban maupun sudut kelalaian korban itu sendiri yang menjadi salah satu faktor pendorong pelaku untuk melakuakan tindak pidana.

Menurut pandangan penulis viktimologi dewasa ini merupakan gagasan atau pemikiran baru dalam ilmu kriminologi, karena telah terjadi pergeseran pemikiran yang tidak lagi melihat kejahatan melalui studi terhadap pelaku kejahatan itu sendiri akan tetapi mengarah pada korban yang menjadi objek pelaku kejahatan. Dalam hal mempelajari korban serta penyebab-penyebab terjadinya tindak pidana, maka viktimologi sendiri berkembang menjadi sarana dalam menanggulangi atau mengantisipasi perkembangan kejahatan dn kriminalitas dalam bentuk tindak pidana yang ada dalam kehidupan masyarakat, sehingga viktimologi sendiri masuk kedalam salah satu proses kebijakan publik.

Berbagai kasus pencemaran nama baik belakangan ini kerap terjadi, khususnya yang dilakuakan melalui dunia maya. Berbagai kasus tersebut memunculkan opini dari sebagian masyarakat yang menganggap pasalpasal delik pencemaran nama baik bertentangan dngan semangat reformasi

\footnotetext{
${ }^{7}$ Angkasa dan Iswanto. 2010. Viktimologi. Purwokerto: Universitas Jendral Soedirman, hlm. 28.
} 
yang menjunjung kebebasan berpendapat dan berekspresi dalam kehidupan berdemokrasi sekarang ini. Seperti halnya kasus pencemaran nama baik yang pernah menyit perhatian publik yang dialami Prita Mulyasari yang mengirim surat elektronik atau e-mail kepada rekanrekannya berisi keluhan atas pelayanan Rumah Sakit (RS) Omni Internasional saat Prita dirawat. Surat elektronik ini kemudian beredar luas ke mailling list, blog, hingga situs jejaring sosial. Surat elektronik itulah yang diadukan manajemen RS Omni Internasional kepada Polisi sebagai pencemaran nama baik. Prita diadukan secara pidana. Di samping itu, Prita juga digugat secara perdata. Hanya berselang dua hari setelah gugatan perdata RS Omni Internasional dikabulkan oleh pengadilan, Prita langsung ditangkap dan dijebloskan ke dalam penjara Tanggerang. ${ }^{8}$

Sama halnya dengan kasus diatas salah satu kasus yang diteliti oleh peneliti yaitu mengenai victim precipitation adalah perkara yang terdapat dalam Putusan nomor 310/Pid.Sus/2017/PN. Idm. Pada awalnya kasus yang dialami terdakwa sendiri bermula pada saat yang bersangkutan menulis cuitan keluh kesahnya di media sosial dengan menggunakan media sosial facebook dan BBM, karena terdakwa yang merasa kesal atas adanya dugaan tindak pidana yang dialaminya yang diduga dilakukan oleh para saksi. Perbuatan Terdakwa diatur dan diancam sebagaimana Pasal 27 ayat (3) Nomor 11 Tahun 2008 tentang Informasi dan Transaksi Elektronik dengan pidana 1 (satu) Tahun 4 (empat) Bulan Penjara menurut Putusan Perkara Nomor 310/Pid.Sus/2017/PN.Idm.

8 Oksidelfa Yanto. 2010. Mafia Hukum Membongkar Konspirasi dan Manipulasi Hukum di Indonesia. Jakarta: Penebar Swadaya Group, hlm.102.
Dari paparan kasus diatas bahwa Victim precipitation harus mendapat perhatian penuh oleh para aparat penegak hukum apakah itu polisi, jaksa dan maupun hakim ketika menangani suatu perkara yang dimana peran korban sama bersalahnya dengan pelaku. Bagaimana seseorang bisa dikatakan menjadi tersangaka jika dihubungkan dengan peran korban dalam suatu tindak pidana. Dijelaskan juga bahwa hak menyampaikan pendapat diatur dalam Pasal 28 f UUD 1945, sebagai berikut.

Setiap orang berhak untuk berkomunikasi dan memperoleh informasi untuk mengembangkan pribadi dan lingkungan sosialnya, serta berhak untuk mencari, memperoleh, memiliki, menyimpan, mengolah dan menyampaikan informasi dengan menggunakan segala jenis saluran yang tersedia.

Dari penjelasan terkait kasus diatas bahwa setiap manusia berhak untuk berkomunikasi dengan siapapun, tanpa terkecuali dan tidaka ada pengaruh dari pihak manapun, sebab dengan adanya komunikasi seseorang akan mengenal dunia luar dan oleh sebab itu dengan berkomunikasi dapat memberikan informasi dari bebagai sumber terutama di media sosial dan secara tidak langsung wawasan bertambah. Sepanjang tidak merugikan diri sendiri ataupun orang lain, oleh karenanya dengan adanya Undangundang Nomor 11 Tahun 2008 tentang Informasi dan Transaksi Elektronik (ITE) yang diharapkan dapat menjadi payung hukum dalam mengatur aktivitas di media sosial itu sendiri.

Berdasarkan pandangan peneliti dalam penjelasan peraturan tersebut diatas yaitu peraturan tersebut jika dihubungkan dengan vctim precipitation apakah kualifikasi tentang korban sudah diatur dari berbagai aspek, terutama jika dalam keadaan tertentu terjadi 
suatu peristiwa hukum yang menyebabkan adanya kausalitas antara korban dan pelaku dalam suatu tindak pidana terkait kejahatan informasi dan transaksi elktronik tersebut. Menurut hematnya dari segi pertanggung jawaban pelaku maupun korban harus dijelaskan secara rinci dalam undang-undang tersebut, sehingga terciptanya keadilan yang diharapkan ideal.

Dalam hal ini juga peran penegak hukum terkhusus seorang hakim harus jeli dalam menangani suatu kasus yang seperti yang sudah disebutkan diatas agar dapat memahami dan mempertimbangkan victim precipitation agar dapat menjadi dasar pertimbangan hukum yang dapat dianggap adil bagi pihak korban dan pelaku itu sendiri. Vvictim precipitation bukan hanya sebagai dasar doktrin melsinkan dapat dimasukan dalam pertimbangan hakim dalam memutus suatu perkara.

Selanjutnya bahwa pemidanaan yang selama ini hanya sebagai pembalasan atas kesalahan pelaku, maka dengan mengetahui victim precipitation dalam terjadinya tindak pidana akan tercapai tujuan yang lebih tingi yaitu pemidanaan sebagai sarana untuk mencapai tujuan bermanfaat untuk melindungi masyarakat menuju kesejahteraan. Victim precipitation dapat digunakan sebagai sarana pencegahan terjadinya tindak pidana, yaitu agar masyarakat dapat lebih berhati-hati dalam melakukan perbuatan yang dapat mengakibatkan dirinya menjadi korban tindak pidana karena kelalaiannya sendiri. Hal ini selaras dengan teori relatif dalam hukum pidana yaitu :

Teori relatif memandang pemidanaan bukan sebagai pembalasan atas kesalahan si pelaku, melainkan sebagai sarana mencapai tujuan bermanfaat untuk melindungi masyarakat menuju kesejahteraan. Dari teori ini muncul tujuan pemidanaan sebagai pencegahan, yaitu pencegahan umum yang ditujukan pada masyarakat. Berdasarkan teori ini, hukuman yang dijatuhkan untuk melaksanakan maksud atau tujuan dari hukuman itu yakni memperbaiki ketidakpuasan masyarakat sebagai akibat kejahatan mmperbaiki ketidakpuasan msyarakat sebagai akibat kejahatan itu. Tujuanhukuman harus dipandang secara ideal, selain dari itu, tujuan hukuman adalah untuk mencegah (prevensi) kejahatan. ${ }^{9}$

Berdasarkan teori relatif, pidana bukanlah sekedar untuk melakukan pembalasan atau pengimbalan kepada orang yang telah melakukan suatu tindak pidana, tetapi mempunyai tujuan-tujuan tertentu yang bermanfaat. Pembalasan itu sendiri tidak mempunyai niali, tetapi hanya sebagai sarana untuk melindungi kepentingan masyarakat. Dasar pembenaran pidana terletak pada tujuannya adalah untuk mengurangi frekuensi kejahatan. Pidana dijatuhkan buan karen orang membuat kejahatan, melainkan supaya orang jangan melakukan kejahatan. ${ }^{10}$

Dari kasus mengenai Victim precittation dalam Putusan nomor 310/Pid.Sus/2017/PN.Idm. Menurut pandangan penulis terdapat victim precipitation sebagai stimulus terdakwa melakukan tindak pidana. Dan Hakim dalam putusanya tidak menggunakan Victim precipitation dalam menjatuhkan Putusannya sebagai hal yang meringankan atau memberatkan pidana terdakwa dalam pertimbangannya, sehingga menjadi alasan menarik oleh penulis untuk diteliti.

\footnotetext{
${ }^{9}$ Leden Marpaung. 2009. Asas-teori-Praktek Hukum Pidana. Jakarta: Sinar Grafika, hlm. 106.

${ }^{10}$ Dwidja Priyatno. 2009. Sistem Pelaksanaan Pidana Penjara di Indonesia. Bnadung: Penerbit Refika Aditama, hlm. 26.
} 


\section{B. Perumusan Masalah}

Berdasarkan uraian dan latar belakang diatas, maka yang menjadi pokok permasalahan dalam penulisan ini adalah:

1. Apakah terdapat victim precipitation dalam terjadinya kasus penghinaan dan pencemaran nama baik di media sosial terhadap Putusan Perkara (Nomor

310/Pid.Sus/2017/PN.Idm). di wilayah hukum Pengadilan Negeri Indramayu ?

2. Mengapa hakim tidak mempertimbangkan aspek victim precipitation didalam putusannya pada kasus tindak pidana penghinaan dan pencemaran nama baik di media sosial terhadap Putusan Perkara (Nomor 310/Pid.Sus/2017/PN.Idm). di wilayah hukum Pengadilan Negeri Indramayu?

\section{Metode Penelitian}

Metode pendekatan yang dipergunakan dalam penelitian ini adalah metode kualitatif dengan pendekatan yuridis sosiologis (sosio-legal research). Menurut Soerjono Sukanto bahwa penelitian hukum sosiologis atau empiris yang mencakup penelitian terhadap identifikasi hukum (tidak tertulis) dan penelitian terhadap efektifitas hukum. ${ }^{11}$ Melalui pendekatan yuridis sosiologis penulis ingin mengetahui dan mengkaji lebih dalam tentang victim precipitation dalam tindak pidana pengihinaan dan pencemaran nama baik di media sosial dapat mempengaruhi putusan hakim

${ }^{11}$ Soerjono Sukanto. 2010. Pengantar Peneliti Hukum. Jakarta: UII Pres, hlm. 15. serta alasan hakim tidak menggunakan victim precipitation dalam mempertimbangkan putusan hakim dalam kasus tindak pidana penghinaan dan pencemaran nama baik di media sosial diwilayah hukum Pengadilan Negeri Indramayu.

Spesifikasi penelitian ini bersifat deskriptif sesuai dengan masalah dan tujuan dalam penelitian ini. Deskriptif ini bukan dalam arti sempit, artinya dalam memberikan gambaran tentang fenomena yang ada dilakukan sesuai dengan metode penelitian. Menurut Soerjono Sukanto bahwa penelitian depkriptif bukan semata-mata untuk mengungkapkan atau menggambarkan kesesuaian perundang-undangan dalam realita kehidupan masyarakat belaka, akan tetapi juga untuk memahami pelaksanaan peraturan perundangundangan tersebut berlandaskan pada peraturan hukum dan memahami apa yang menjadi latar belakang dari pelaksanaan tersebut. ${ }^{12}$

Sumber data terdiri dari 2 (dua) sumber data, yaitu:

a. Sumber data primer

Sumber data primer yaitu data yang langsung dikumpulkan oleh peneliti (atau petugasnya) dari sumber pertamanya. Data primer merupakan data yang bersumber dari pendapat langsung oleh narasumber. ${ }^{13}$ Dalam hal ini penulis menggunakan data hasil wawancara dengan hakim di Pengadilan Negeri Indramayu.

b. Sumber data sekunder

\footnotetext{
${ }^{12}$ Soerjono Sukanto. 1986. Penelitian Hukum. Jakarta: Universitas indonesia, hlm. 25.

${ }_{13}$ Peter Mahmud Marzuki. Penelitian Hukum, EdisiRevisi. Jakarta: Kencana Prenadamedia, hlm. 187.
} 
Sumber data sekunder yaitu data yang langsung dikumpulkan oleh peneliti sebagai penunjang dari sumber pertama. Dapat juga dikatakan data yang tersusun dalam bentuk dokumen-dokumen. Sumber data sekunder yang digunakan dalam penelitian ini tersusun dalam bentuk dokumen-dokumen atau literature, referensi serta hasil dari penelitian yang berkaitan dengan topik penelitian. ${ }^{14}$ Dalam hal ini sumber data yang digunakan penulis antara lain UUD 1945, KUHP, Undangundang Informasi dan Transasksi Elektronik, (Undang-undang Republik 19 Tahun 2016 Tentang Perubahan Atas Undang-undang Nomor 11 Tahun 2008).

Analisis data dalam penelitian ini menggunakan metode kualitatif. Metode kualitatitf yaitu menguraikan bahan hukum secara bermutu dan bentuk kalimat yang teratur, runtun, logis, tidak tumpang tindih dan efektif. Peneliti akan menganalisis bahan hukum berdasarkan logika dan peraturan perundang-undangan yang memiliki kualitas sebagaimana bahan hukum yang diperlukan dan/atau bahan hukum mana yang tidak diperlukan atau tidak ada hubungannya dengan materi penelitian. Bahan hukum dalam penelitian ini berupa peraturan perundang-undangan, hasil wawancara, dokumentasidokumentasi, buku, jurnal ilmiah, dan bahan hukum lainnya yang berkaitan dengan penelitian yang akan diteliti. ${ }^{15}$

\section{Hasil Penelitian dan Pembahasan}

1. Hasil Penelitian

a. Kronologi Peristiwa

Terdakwa Eko Indraprasda Musdiono Bin Edy Prasetyo pada hari Kamis tanggal 05 Mei 2016 sekira pukul 21.36 WIB atau setidaknya pada waktu lain dalam bulan Mei tahun 2016, bertempat di rumah terdakwa yang terletak di Jl. Adipati No.26 Rt.02/06 Kel. Margadadi, Kec. Indramayu, Kab. Indramayu atau setidak-tidaknya ditempat lain dalam daerah hukum Pengadilan Indramayu yang berwenang dan mengadili "dengan sengaja dan tanpa hak mendistribusikan dan/atau mentransmisikan dan/atau membuat dapat diaksesnya informasi elektronik dan/atau dokumen elektronik yang memiliki muatan penghinaan dan/atau pencemaran nama baik", yang dilakukan dengan cara-cara dan kejadiannya sebagai berikut:

Awal mulanya terdakwa merasa telah dianiaya atau dikeroyok oleh saksi yaitu Habib Burrohman dan saksi Hilal Hilmawan pada hari Kamis tanggal 05 Mei 2016. Sekira pukul 20.30 WIB ketika sedang nongkrong di Sprot Center Kel. Karanganyar, Kab. Indramayu bersama dengan teman-temanya terdakwa yang diantaranya yaitu saksi Robi Alamsyah dan Tarsana.

Terdakwa yang merasa kesal atas dugaan kejadian penganiayaan atau pengroyokan yang dialaminya

\footnotetext{
${ }^{15}$ Sumadi Surya Brata. Op.Cit., hlm. 95.
} 
tersebut ternyata saat itu tidak sekitika melaporkannya kepada petugas kepolisian, melainkan terdakwa pada sekira pukul 21.36 WIB justru melampiaskan kekesalannya dengan menuduh saksi Hilal Hilmawan sebagai preman atau pelaku kriminal atau penjahat yang telah melakukan penganiayaan atau pengroyokan tersebut, yaitu dengan cara terdakwa melakukan update status pada akun Facebook miliknya (Eko Indraprasda musdiyono) menggunakan Hand Phone miliknya dengan kata-kata: "Hilal Hilmawan kamu preman Indramayu tah sya cari kamu, kamu maksudnya apa premanismee gt sya udh ada bukti. Masukan ranah hukum. Pemuda Pancasila bukan kumpulan preman kaya kamu."

Jadi menurut pandangan penulis bahwa, dari pengakuan pelaku bahwa dia merasa manjadi korban suatu tindak kejahatan yang dilakukan oleh korban sehingga perlakuan korban tersebut membuat pelaku disini merasa emosi dan mengutarakan perasaannya di media sosial sehinggga peran korban tersebut sebagai stimulus pelaku dalam melakukan tindak pidana penghinaan dan pencemaran nama baik di media sosial.

Terdakwa yang mengetahui Habib Burrohman merupakan Ketua Ormas Sapma PP (Satuan Pelajar dan Mahasiswa Pemuda Pancasila) Kab. Indramayu pada saat itu, kembali melampiaskan kekesalannya dengan menuduh Ormas Sapma PP Kab. Indramayu sebagai kumpulan para pelaku kriminal atau penjahat serta budak bayaran, yaitu dengan cara terdakwa membuat status pada aplikasi Blackberry Massager (BBM) miliknya menggunakan Hand Phone miliknya menulisan kata-kata "PP tuh ormas atau kumpulan preman? ormas di Indonesia Cuma PP aja th yg menurut dia merasa hebat? maju tak gentar dan sapma PP Indramayu itu kumpulan para preman atau kumpulan para jongosnya Yance."

Setelah terdakwa menuliskan kata-kata tersebut, barulah esoknya pada hari Jum'at tanggal 06 Mei 2016 terdakwa melaporkan kepada petugas Polres Indramayu atas dugaan penganiayaan atau pengroyokan yang dialaminya, memang berdasarkan keterangan saksi Robi Alamsyah yang ada ditempat kejadian perkara menerangkan tidak ada ada pemukulan yang dilakukan oleh saksi Habib Burrohman dan saksi Hilal Hilmawan terhadap terdakwa pada hari Kamis tanggal 05 Mei 2016 sekira pukul 20.30 WIB di Sprot Center Kel. Karanganyar Kab. Indramayu.

Dari pandangan penulis disini bahwa peran korban disimpulkan berperan aktif sehingga menyulut kemarahan korban hingga mencurahkan kekesalanya di media sosial sebagai bentuk kekesalan pelaku terhadap korban maupun cara yang dilakukan salah hingga menghina korban dan organisasi tertentu sebagai preman dan jongos yang dimana menurut penulis katakata tersebut memuat ujaran sarkasme dalam tulisanya itu. Akan tetapi dari keterangan saksi yang ada ditempat kejadian perkara bahwa 
1551 | Jurna I Id e a H u k u m

Vol. $5 \mathrm{No} .2$ Oktober 2019

Magister II muHukum Universitas Jenderalsoedirman

dapat disimpulkan oleh penulis korban berperan aktif dalam serangkain kejadian tersebut sehingga adanya kausalitas dalam kasus ini. Sebagaimana keaktifan korban dalam hal ini dijelaskan oleh Tarsana yang juga menjadi saksi di tempat kejadian perkara bahwa adanya peran aktif korban dengan menghampiri pelaku hingga terjadi cekcok dan adanya penarikan baju hingga terjatuh.

Kata-kata yang ditulis oleh terdakwa melalui update status pada akun facebook dan aplikasi BBM milikny tersebut ahirnya telah atau dibaca oleh orang lain diantaranya yaitu Anwar Syahdath, Sarah Dewi, Awwaludin Romadlon, Ambriyanto, Zakiyalanabil, saksi Ade Renaldi alias Bembi, saksi Lien Barlindasari Virginia, saksi Ananda Putri Zulfianti dan saksi Nurhadi alias Klawer yang kemudiam tulisan terdakwa tersebut di screenshot dan diperlihatkan kepada saksi Habib Burrohman dan saksi Hilal Hilmawan.

Yang pada intinya menurut pandangan penulis dalam kasus Penghinaan dan pencemaran nama baik ini kata-kata yang ditulis oleh terdakwa dapat di baca oleh beberapa saksi yang melihat tulisanya di media sosial, sehingga tulisan tersebut dapat diakses oleh pembaca di media sosial.

Saksi Habib Burrohman selaku Ketua Ormas Sapma PP serta saksi Hilal Hilmawan selaku Dosen di Universitas Wiralodra Kab. Indramayu setelah mengetahui adanya tulisan yang dibuat oleh terdakwa melalui akun facebook dan aplikasi BBM tersebut pada ahirnya merasa terhina, malu dan tersinggung telah dicemarkan nama baik dan kehormatannya sehingga mengadukan dan melaporkan terdakwa kepada pihak Kepolisian untuk diproses secara hukum karena tulisan terdakwa tersebut ternyata isinya tidak benar dan bukan dilakukan demi kepentingan umum atau karena terpaksa untuk membela diri.

Sehingga perbuatan terdakwa sebagai mana diatur diancam pidana berdasarkan Pasal 27 Ayat 3 jo. Pasal 45 Ayat 1 Undang-Undang Nomor 11 tahun 2008 tentang informasi dan transaksi elektronik. ${ }^{16}$ Yang merumuskan bahwa:

\begin{tabular}{lrr} 
"Melarang setiaporang denan & \multicolumn{1}{c}{ denaj } \\
sengaja dan tanpa hak \\
mendistribusikan dan/atau \\
mentransmisikan ran dan/atau \\
membuat dapat diaksesnya \\
Informasi elektronik dan/atau \\
Dokumen Elektronik yang \\
memiliki muatan penghinaan \\
dan/atau pencemaran nama \\
baik".
\end{tabular}

Penjelasan Pasal 45 Ayat (1) yang merumuskan:

"Setiap orang yang memenuhi unsur sebagaimana dimaksud dalam pasal 27 ayat (1), ayat (2), ayat (3), atau ayat (4) dipidana penjara paling lama 6 (enam) tahun dan/atau denda paling banyak Rp. 1.000.000.000,00 (satu miliar rupiah)".

Pencemaran nama baik di media sosial, sudah masuk dalam delik perbuatan pidana. Baik dengan pasal penghinaan individu maupun pencemaran nama baik yang diatur

\footnotetext{
${ }^{16}$ Putusan Nomor 310/Pid.Sus/2017/PN.Idm, hlm. 3-7.
} 
dalam KUHP maupun UU ITE. Jika pencemaran nama baik ini di teruskan secara terus menerus, orang akan menggunakan media sosial sebagai sarana untuk memncaci-maki baik terhadap individu maupun kelompok. Jadi alasan terdakwa bisa dihukum disini bukan hanya dianggap melanggar hukum, melainkan juga melanggar etika dan moral.

b. Victim Precipitation dalam Tindak Pidana

Viktimologi mempunyai fungsi untuk mempelajari sejauh mana peran dari seseorang korban dalam terjadinya tindak pidana, serta bagaimana perlindungan yang harus diberikan oleh pemerintah terhadap seseorang yang telah menjadi korban kejahatan. Dalam hal ini, dapat dilihat bahwa korban juga ikut berperan dalam terjadinya tindak pidana pengihinaan dan pencemaran nama baik di media sosial, walaupun dalam hal ini korban bersifat pasif namun korban juga memiliki andil yang fungsional dalam terjadinya kejahatan. Pada kenyataannya dapat dikatakan bahwa tidak mungkin timbul suatu kejahatan kalau tidak ada si korban kejahatan, yang merupakan peserta utama dan si penjahat atau pelaku dalam hal ini terjadinya suatu kejahatan dan hal pemenuhan kepentingan si pelaku yang terakibat pada penderitaan korban. Dengan demikian dapat dikatakan bahwa korban mempunyai tanggung jawab fungsional dalam terjadinya kejahatan. ${ }^{17}$

\begin{abstract}
Melalui viktimologi dapat diketahui berbagai aspek yang berkaitan dengan korban seperti faktor penyebab munculnya kejahatan, bagaimana seseorang dapat menjadi korban, upaya mengurangi terjadnya korban kejahatan, hak dan kewajiban korban kejahatan. ${ }^{18}$ Dalam kajian viktimologi terdapat perspketif dimana korban bukan saja bertanggung jawab dalam kejahatan itu sendiri tetapi juga memiliki keterlibatan dalam terjadinya kejahatan. Menurut Stephen Schafer, terdapat 7 (tujuh) tipe korban yang di tinjau dari pespketif tanggung jawab korban itu sendiri, diantaranya yaitu:
\end{abstract}

1. Unrelated Victims adalah mereka yang tidak ada hubungan dengan si pelaku dan menjadi korban karena memang potensial. Untuk itu, dari aspek tanggung jawab sepenuhnya berada dipihak korban.

2. Provocative Victims adalah korban yang disebabkan peranannya korban untuk memicu terjadinya kejahatan. Karena itu, dari aspek tanggung jawab terletak pada diri korban dan pelaku secara bersama-sama.

3. Participating Victim, hakikatnya perbuatan korban tidak disadari dapat mendorong pelaku melakukan kejahatan. Aspek ini pertanggungjawaban sepenuhnya ada pada pelaku.

4. Biologically Weak Victims adalah kejahatan disebabkan adanya keadaan fisik korban seperti wanita, anak-anak, dan manusia lanjut usia (manula) merupakan potensial korban kejahatan. Ditinjau dari aspek pertanggungjawabannya terletak pada masyarakat atau pemerintah setempat karena tidak dapat memberi perlindungan kepada korban yang tidak berdaya. 
5. Social Weak Victims adalah korban yag tidak diperhatikan oleh masyarakat bersangkutan seperti para gelandangan dengan kedudukan sosial yang lemah. Untuk itu, pertanggungjawabannya secara penuh terletak pada penjahat atau masyarakat.

6. Selfvictimizing Victims yaitu korban kejahatan yang dilakukan sendiri (korban semu) atau kejahatan tanpa korban. Pertanggungjawabannya sepenuhnya terletak pada korban karena sekaligus sebagai pelaku kejahatan.

7. Political Victims yaitu korban karena lawan politiknya. Secara sosiologisnya, korban ini tidak dapat dipertanggungjawabkan kecuali adanya perubahan konstelasi politik. ${ }^{19}$

c. Ketentuan Hukum Tentang

Pencemaran Nama Baik Di Media Sosial

Berdasarkan Pasal 310 KUHP dan 27 Ayat 3 UU ITE Nomor II tahun 2008, untuk dapat dkategorikan sebagai tindak pidana pencemaran nama baik, maka harus dibuktikan adanya unsur-unsur dirumuskan sebagai berikut, yaitu:

1. Adanya kesengajaan.

2. Tanpa hak (tanpa ijin).

3. Bertujuan untuk menyerang nama baik atau kehormatan.

4. Agar diketahui oleh umum.

Dari penjelasan diatas menjelaskan bahwa syarat untuk dapat dipidananya seseorang bukan hanya perbuatannya yang bersifat melawan hukum, tetapi juga harus dibuktikan adanya kesalahan dalam diri pelaku. Apabila mengcu pada ketentuan Pasal 27 ayat 3 UU ITE maka harus adanya

\footnotetext{
${ }^{19}$ Lilik Mulyadi. 2007. Kapita Selekta Hukum Pidana Kriminologi dan Viktimologi. Denpasar: Djambatan, hlm. 124.
}

unsur kesengajaan oleh pelaku. Oleh karena itu para penegak hukum dari Polisi, Jaksa, dan juga Hakim harus jeli dalam menangani perkara yang berhubungan dengan UU ITE ini. Jadi dalam hal ini unsur subjektif dari sikap batin pelaku itu sendiri hars diperhatikan secara rinci dan jelas, apakah pelaku sebagai korban ataupun pelaku adalah aktor tunggal.

Hasil penelitian dilapangan yang diperoleh melalui wawancara terhadap narasumber atau informan tentang victim precipitation dalam tindak pidana pencemaran nama baik di media sosial menurut Putusan Nomor (310/Pid.Sus/2017/PN.Idm) di wilayah hukum Pengadilan Negeri Indramayu, adalah sebagai berikut ;

a. Unggul Tri Esthi Muljono (Hakim Ketua Pengadilan Negeri Indramayu) dalam Putusan Nomor: (310/Pid.Sus/2017/PN.Idm)

Pandangan mengenai Victim Precipitation dan Alasan Hakim tidak mempertimbangkan victim precipitation dalam menjatuhkan putusan, yaitu:

"Menyatakan bahwa victim precipation memandang korban secara tidak murni dalam artian korban sebagai penyebab terjadinya kejahatan. Kejahatan dapat terjadi akibat adanya provokasi terlebih dahulu oleh korban. Terjadinya tindak pidana tidak sepenuhnya dikarenakan peran pelaku tetapi juga karena adanya peran korban. Dan dalam kasus tersebut hakim mengutarakan bahwa alasan pemberat dalam piutusanya karena pelaku dinyatakan 
bersalah dalam kasus ITE tersebut karena dalam persidangan mengakui dan menyadari atas perbuatan yang dilakukan tersebut untuk peran korban hakim berpendapat bahwa menyatakan tidak berperan aktif karena yang dituduhkan oleh pelaku belum cukup bukti dalam persidangan terutama kesaksian para saksi dipersidangan mengatakan tidak ada penganiyayaan hanya korban menghampii pelaku terlebih dahulu dan cekcok, hambatan yang terjadi ialah hakim disini tidak serta merta mempercayai apa yang dikatakan para saksi terutama saksi yang ada di tempat kejadian perkara karena hakim tidak ada dalam kejadian tersebut maka hakim juga memanfaatkan keterangan saksi ahli dalam memperjelas perkara dan menjadi dasar pertimbangan hakim menurut keyakinannya".

\section{b. Adil Hakim (Hakim Anggota}

Pengadilan Negeri Indramayu)

Pandangan mengenai Victim Precipitation dan Alasan Hakim tidak mempertimbangkan victim precipitation dalam menjatuhkan putusan, yaitu:

"Menyatakan bahwa victims precipation dalam terjadinya tindak pidana mengemukakan bahwa korban mempunyai peran penting dalam terjadinya tindak pidana. Peranan tersebut baik dalam keadaan sadar ataupun tidak sadar, secara langsung ataupu tidak langsung. Korban juga dapat berpartisipasi aktif maupun pasif semua tergantung pada situasi dan kondisi pada saat kejahatan tersebut terjadi, sehingga menjadi alasan pemberat dan meringankan dalam amar putusan. Dan menurut Adil Hakim bahwa jika victim precipitation diberlakukan dalam kasus tersebut maka pelaku dikatakan lebih bersalah daripada korban karena kurangnya pembuktian di persidangan terkait apa yang dituduhkan oleh pelaku terhadap korban yang telah menganiaya dirinya, bahkan dia mengatakan korban sama sekali tidak berperan aktif dan Hakim disini memutus menurut bukti-bukti yang dijelaskan oleh penutut umum di persidangan dan para saksi yang dihadirkan di persidangan sebagai dasar tuntutan dan dasar pertimbangan hakim. ${ }^{20}$

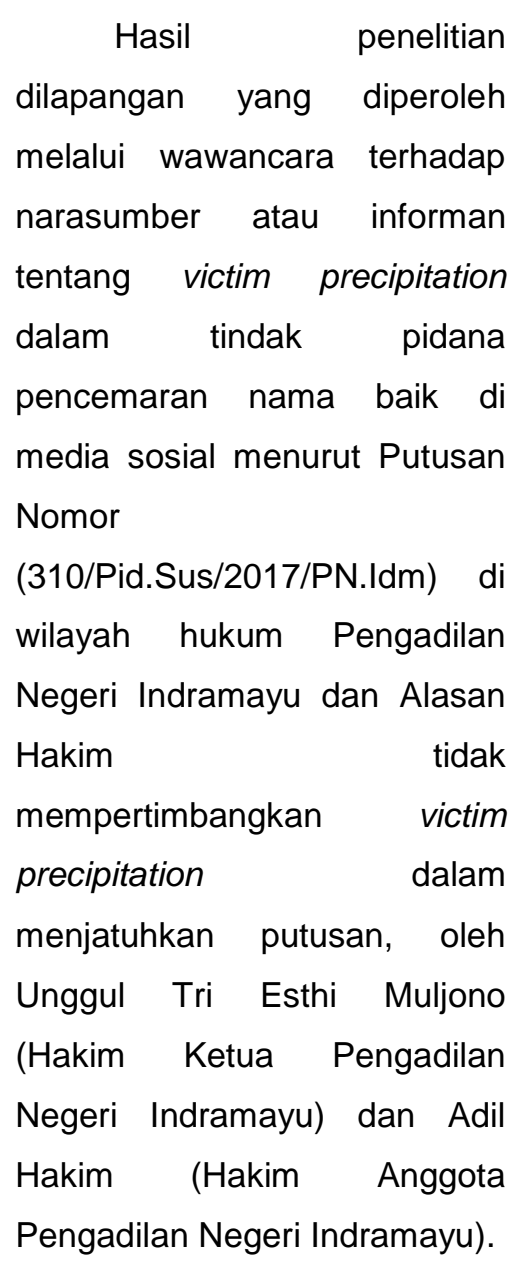

\footnotetext{
${ }^{20}$ Wawancara dengan Narasumber Unggul Tri Esthi Muljono dan Adil Hakim. Hakim Ketua Pengadilan Negeri Indramayu, Hari Kamis 13 September 2018, Pukul 10.00 WIB.
} 
Peran korban merupakan faktor pendukung selain pelaku dalam terjadinya tindak pidana. Hal tersebut dapat dijadikan sebagai pertimbangan hakim dalam menjatuhkan sanksi pidana. Pertimbangan tersebut berkaitan dengan kesalahan mutlak dilakukan oleh pelaku tindak pidana atau tidak. Perlu pemahaman yang lebih dalam terhadap tipologi korban agar tidak menimbulkan keadilan yang berat sebelah tanpa memandang kepentingan korban dan kepentingan pelanggar.

Terdapat aspek victim precipation dalam kasus penghinaan dan pencemaran nama baik dimedia sosial yang mengakibatkan rasa kesal atau dendam antara si pelaku dan si korban. Pelaku dan korban sama-sama melapor akan terjadinya kasus tindak pidana tersebut. Yang mana dalam hal ini, korban sebenarnya hanya menegur pelaku dengan sebuah kata-kata yang dilontarkan langsung kepada pelaku dan tidak adanya penganiayaan (pukul-pukulan).

Dalam hal ini tidak akan terjadi kasus penghinaan dan pencemaran nama baik dimedia sosial jika tidak ada provokasi terlebih dahulu dari si korban. Majelis hakim dalam hal ini tidak menyebut secara eksplisit mengenai victim precipation dikarenakan hal tersebut hanya merupakan teknis penulisan saja, namun alangkah baiknya victim precipation tetap harus digunakan dalam pertimbangan majelis hakim dalam menjatuhkan putusannya. ${ }^{21}$

\section{Hasil Pembahasan}

a. Terjadinya Victim Precipitation dalam tindak pidana penghinaan dan pencemaran nama baik di media sosial dalam putusan (Nomor: 310/Pid.Sus/2017/PN.Idm.

Dari kronologi peristiwa yang terjadi dalam kasus Penghinaan dan pencemaran nama baik di media sosial pada putusan Nomor: 310/Pid.Sus/2017/PN.Idm. bahwa, dari pengakuan pelaku Eko Indraprasada Musdiono dia merasa manjadi korban suatu tindak kejahatan penganiyayan dan pengeroyokan yang dilakukan oleh korban sehingga perlakuan korban tersebut membuat pelaku disini merasa emosi dan mengutarakan perasaannya di media sosial sehinggga peran korban tersebut sebagai stimulus pelaku dalam melakukan tindak pidana penghinaan dan pencemaran nama baik di media sosial.

Sehingga perbuatan terdakwa sebagai mana diatur diancam pidana berdasarkan Pasal 27 Ayat 3 jo. Pasal 45 Ayat 1 Undang-Undang Nomor 11 tahun 2008 tentang

\footnotetext{
${ }^{21}$ Wawancara dengan Narasumber Unggul Tri Esthi Muljono dan Adil Hakim. Hakim Ketua Pengadilan Negeri Indramayu, Hari Kamis 13 September 2018, Pukul 10.00 WIB.
} 
informasi dan transaksi elektronik. ${ }^{22}$ Yang merumuskan bahwa:

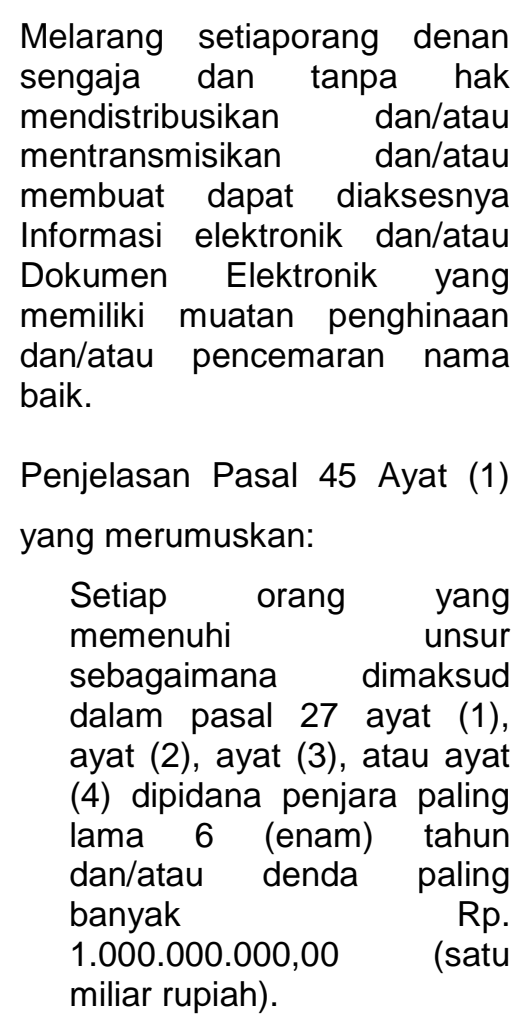

Stimulus yang dilakukan oleh korbanlah yang menurut penulis termasuk dalam Aspek victim precipation dalam tindak pidana penghinaan dan pencamaran nama baik di media sosial dalam putusan Nomor 310/Pid.Sus/2017/PN.Idm, Bahwa, korban merupakan objek dalam kajian viktimologi yaitu sebagai salah satu faktor terjadinya viktimisasi. Pada kasus ini, korban melakukan perbauatan yang mendorong emosi pelaku sehingga melakukan tindak pidana. $\mathrm{Hal}$ tersebut sebagaimana yang dikemukana oleh Arif Gosita bahwa yang menjadi objek kajian viktimologi adalah:

1) Pihak-pihak mana saja yang terlibat atau mempengaruhi terjadinya suatu viktimisasi (kriminal).

2) Bagaimanakah respon terhadap suatu viktimisasi kejahatan.

3) Faktor penyebab terjadinya viktimisasi kejahatan. ${ }^{23}$

Dalam putusan Nomor 310/Pid.Sus/2017/PN.Idm, berdasarkan keterangan saksi yang ada di tempat kejadian perkara, pandangan penulis disini bahwa peran korban disimpulkan berperan aktif sehingga menyulut kemarahan korban hingga mencurahkan kekesalanya di media sosial sebagai bentuk kekesalan pelaku terhadap korban maupun cara yang dilakukan oleh Terdakwa salah hingga menghina korban dan organisasi tertentu sebagai preman dan jongos yang dimana menurut penulis kata-kata tersebut memuat ujaran sarkasme dalam tulisanya itu. Akan tetapi dari keterangan saksi yang ada ditempat kejadian perkara dapat disimpulkan bahwa korban berperan aktif dalam serangkain kejadian tersebut sehingga adanya kausalitas dalam kasus ini. Sebagaimana keaktifan korban dalam hal ini dijelaskan oleh salah saksi yaitu Tarsana yang juga menjadi saksi di tempat kejadian perkara bahwa adanya peran aktif korban dengan menghampiri pelaku hingga terjadi cekcok dan adanya penarikan baju hingga terjatuh.

Oleh karena itu tindakan korban didalam kasus ini termasuk ke dalam kategori victim precipitation Mendelshon mengklasifikasikan korban dalam 6 (enam) kategori, yaitu: 
a. Korban yang sama sekali tidak bersalah yaitu seorang anak atau orang yang benar-benar tidak sadar, korban tidak bertanggungjawab atas terjadinya victimisasi.

b. Korban memiliki kesalahan yang lebih kecil dibanding pelaku yaitu korban karena tindakan yang tidak disengaja, contohnya wanita yang keguguran dan meninggal.

c. Korban sama salahnya dengan pelaku, yaitu mereka yang membantu terjadinya viktimisasi.

d. Korban lebih bersalah dari pelaku yaitu korban memprovokasi orang lain untuk melakukan kejahatan.

e. Korban guilty yaitu korban yang beraksi secara agresif dan terbunuh oleh terdakwa yang bertindak membela diri.

f. Korban imajiner yaitu orang yang menderita penyakit jiwa/kelainan yang percaya bahwa mereka adalah korbannya. ${ }^{24}$

b. Alasan Hakim tidak mempertimbangkan aspek victim preciipation didalam putusannya dalam tindak pidana penghinaan dan pencemaran nama baik di media sosial dalam putusan (Nomor: 310/Pid.Sus/2017/PN.Idm)

Dalam wawancara pada Tanggal 13 September 2018 Pukul 10.00 WIB, Unggul Tri Esthi Muljono (Hakim Ketua Pengadilan Negeri Indramayu) dan Adil Hakim (Hakim Anggota Pengadilan Negeri Indramayu) yang menangani perkara dalam putusan Nomor: 310/Pid.Sus/2017/PN.Idm, menguraikan beberapa pendapat terkait dengan victim precipation dalam tindak pidana penghinaan dan pencemaran nama baik dimedia sosial dan alasan-alasan hakim dalam memutus kasus tersebut.

\footnotetext{
${ }^{24}$. Rena Yulia. Op.Cit., hlm. 76.
}

Majelis hakim dalam hal ini tidak mempertimbangkan mengenai victim precipation dalam putusan Nomor 310/Pid.Sus/2017/PN.Idm, yaitu sebagai hal yang meringankan ataupun memberatkan pidana terdakwa. Berdasarkan hasil wawancara sebagaimana diuraikan dari hasil penelitian dalam data primer di atas menurut hematnya majelis hakim juga telah meyakini menurut keyakinannya bahwa tidak terdapat victim precipation dalam perkara Nomor 310/Pid.Sus/2017/PN.Idm dengan alasan hanya berfokus pada tuntututan yang diberikan oleh penuntut umum saja bahwa yang sepenuhnya bersalah hanyalah pelaku dalam tindak pidana ITE itu sendiri. Padahal dari keterangan oleh para saksi yang ada ditempat kejadian bersama dengan pelaku yang pada intinya menyatakan bahwa korban lebih aktif dengan menghampiri pelaku terlebih dahulu sehingga membuat perekcokan dan diduga terjadi tindak kriminal antara korban terhadap pelaku. Kedudukan korban sebagai provocative victim dalam tipologi korban menurut Schafer yaitu korban memancing-mancing pembuat kejahatan untuk melakukan kejahatan dengan perilaku tertentu, yang mana dalam hal ini korban Hilal Hilmawan dalam memberikan klarifikasi terhadap terdakwa kurang diterima atas dasar peneguran tentang mengenderai motor dengan tidak mengeraskan atau menggerukan suara sepeda motor dengan keras di depan korban.

Korban dan terdakwa dalam hal ini hanya sebatas hubungan dosen dan mahasiswa, dan pada masa SMP 
korban merupakan kakak kelas dari

Putusan

Nomor

terdakwa. Korban dalam perkara

310/Pid.Sus/2017/PN.Idm bahwa, jika

Nomor 310/Pid.Sus/2017/PN.Idm, juga

termasuk provovative victim walaupun

dalam hal ini korban hanya sebatas

mengklarifikasi namun terdakwa

merasa tidak terima dengan tindakan

yang dilakukan korban sehingga

terdakwa merasa kesal dan langsung melontarkan kata-kata yang kasar di akun facebook dan BMM miliknya sehingga menimbulkan rangsangan kejahatan. Korban merasa terhina dan nama baiknya tercemar akibat dari kata-kata yang di update oleh terdakwa diakun facebook dan BBM.

Hakim juga berpendapat bahwa Pertimbangan mengenai adanya victim precipation penting dan hanya tertulis sebagai suatu literatur yang terdapat dalam viktimologi hukum dalam hal yang dapat meringankan atau memberatkan pidana terdakwa, akan tetapi majelis hakim tidak mempertimbangkan mengenai victim precipation dalam perkara Nomor 310/Pid.Sus/2017/PN.Idm. Menurut informan aspek victim precipation dalam terjadinya tindak pidana tidak dijadikan pertimbangan bagi majelis hakim untuk menjatuhkan putusan pidana kepada terdakwa karena menurut majelis hakim kesalahan mutlak di pihak pelaku, karena majelis hakim dalam memutus hanya mengacu terhadap tuntutan dan dakwaan jaksa penuntut umum saja.

Menurut pandangan

Hakim mengenai victim precipation dalam kasus tindak pidana penghinaan dan pencemaran nama baik di media sosial di wilayah hukum Pengadilan Negeri Indramayu dalam victim precipitation diberlakukan dalam kasus tersebut maka pelaku dikatakan lebih bersalah daripada korban karena kurangnya pembuktian di persidangan terkait apa yang dituduhkan oleh pelaku terhadap korban yang telah menganiaya dirinya, seperti yang dikatakan oleh para saksi dipersidangan yang dimana memberatkan Terdakwa, bahkan dia mengatakan korban sama sekali tidak berperan aktif dan hakim disini memutus menurut apa yang dijelaskan oleh penutut umum sebagai dasar tuntutan.

Tetapi setelah peulis meneliti salah satu penyebab terjadinya tindak pidana dalam kasus tersebut dikarenakan adanya provokasi dari korban. Provokasi yang dimaksud dalam hal ini ada dua bentuk yaitu:

1) Korban memprovokasi pelaku dengan cara menghampiri Trdakwa terlebih dahulu dan menjelek-jelekan pelaku, sehingga pelaku berbicara ke ranah politik.

2) Setelah kejadian tersebut, lama kemudian pelaku akan mengambil kunci motor yang jatuh, kemudian tiba-tiba Sdr. saksi Hilal datang dan saat pelaku sedang membungkuk ada yang memukul dari belakang sebanyak 2 kali sehingga pelaku lari. Kemudian setelah itu, ada salah satu ada yang mengejar pelaku hingga pelaku pada saat itu dipepet dan tersandung ban sepeda motor dan terjatuh. Akibat perbuatan korban, ahirnya 
pelaku pulang dan membuat status dengan kata-kata yang kasar dan menghina si korban di akun Facebook dan BBM.

Dalam perkara Nomor 310/Pid.Sus/2017/PN.Idm penuntut umum telah mempertimbangkan hal-hal sebagai berikut:

1) Awal mulanya terdakwa merasa telah dianiaya atau dikroyok oleh saksi Habib Burrohman dan Saksi Hilal Hilmawan pada hari Kamis tanggal 05 Mei 2016 pukul 20.30 ketika sedang nongkrong di Sprot Center Kel. Karanganyar Kab. Indramayu.

2) Terdakwa merasa kesal atas dugaan kejadian penganiayaan atau pengeroyokan yang dialaminya tersebut saat itu tidak seketika melaporkannya kepada petugas kepolisian melainkan perbuatan terdakwa dilakukan dengan cara melampiaskan kesalahannya dengan menuduh saksi Hilal Hilmawan sebagai preman atau pelaku kriminal atau penajahat yang telah melakukan penganiayaan atau pengeroyokan yaitu dengan cara terdakwa melakukan update status pada akun facebook miliknya.

3) Kemudian terdakwa mengetahui bahwa saksi Habib Burrohman merupakan Ketua Ormas Sapma PP (Satuan Pelajar dan Mahasiswa Pemuda Pancasila) Kab. Indramayu. Kemudian pada saat itu terdakwa kembali melampiaskan kekesalanya dengan menuduh Ormas Sapma PP Kab. Indramayu sebagai kumpulan para pelaku kriminal atau penajahat serta budak bayaran yaitu dengan cara terdakwa membuat status pada aplikasi Blackberry Masanger (BMM) miliknya.

Hal Ini juga dikuatkan dengan keterangan para saksi yang ada di tempat kejadian perkara dan hadir di persidangan dalam putusan Nomor 310/Pid.Sus/2017/PN.Idm , yaitu;

1) Bahwa dari data sekunder dalam hasil penelitian saksi menjelaskan tentang peran korban yang mana dapat disimpulkan korban berperan aktif sehingga menyulut kemarahan terdakwa hingga mencurahkan kekesalanya di media sosial sebagai bentuk kekesalan pelaku terhadap korban maupun cara yang dilakukan salah hingga menghina korban dan organisasi tertentu sebagai preman dan jongos yang dimana menurut penulis kata-kata tersebut memuat ujaran sarkasme dalam tulisanya itu. Akan tetapi dari keterangan saksi yang ada ditempat kejadian perkara bahwa dapat disimpulkan oleh penulis korban berperan aktif dalam serangkain kejadian tersebut sehingga adanya kausalitas dalam kasus ini. Sebagaimana keaktifan korban dalam hal ini dijelaskan oleh Tarsana yang juga menjadi saksi di tempat kejadian perkara bahwa adanya peran aktif korban dengan menghampiri pelaku hingga terjadi cekcok dan adanya penarikan baju hingga terjatuh. 
2) Bahwa dari keterangan saksi yang ada dilapangan penulis menyimpulkan adanya kejanggalan yang dimana saksi Habib/Omen menanyakan suatu yang tidak jelas kepada terdakwa sehingga terdakwa merasa ada yang aneh karena menurut penulis saksi disini seolah-olah mencari suatu kesalahan terdakwa agar terdakwa mengakuinya sehingga saksi mengajak korban untuk menyelesaikan masalah dengan cara yang dilakuan oleh saksi Habib/Omen tersebut. Hal tersebut juga dikuatkan dengan keterangan saksi roby yang dimana permasalahan tersebut suatu hal yang membingungkan. Disini dapat disimpulkan bahwa korban berperan aktif kepada pelaku dengan cara menghampiri pelaku dan mencari-cari kesalahan pelaku.

\section{E. Simpulan dan Saran}

1. Simpulan

a. Terjadinya victim precipitation terjadi dalam tindak pidana penghinaan dan pencemaran nama baik di media sosial dalam Putusan Nomor 310/Pid.Sus/2017/PN.Idm adalah karena adanya tindakan provokatif korban (provocative victim) yaitu adanya pengaruh korban yang memancing adanya sebuah kejahatan. Korban mencoba memancing pelaku dengan melakukan klarifikasi/melerai tentang tindakan korban mengenai tata cara mengendari kendaraan bermotor yang baik dan tidak mengganggu kenyamanan dan pelaku dituduh menjelek-jelekan namanya. Pelaku yang merasa tidak terima dengan hal ini sehingga terdakwa melampiaskan kekesalannya dengan menuduh korban sebagai preman atau pelaku kriminal atau penjahat yang telah melakukan penganiayaan atau pengroyokan tersebut, yaitu dengan cara terdakwa melakukan update di akun media sosialnya.

b. Hakim tidak mempertimbangkan aspek victim preciipation didalam putusannya dalam tindak pidana penghinaan dan pencemaran nama baik di media sosial dalam Putusan Nomor 310/Pid.Sus/2017/PN.Idm karena alasan pemberat dalam putusannya karena pelaku dinyatakan bersalah dalam kasus ITE tersebut karena dalam persidangan mengakui dan menyadari atas perbuatan yang dilakukan tersebut. Untuk peran korban hakim berpendapat bahwa menyatakan tidak berperan aktif karena yang dituduhkan oleh terdakwa belum cukup bukti serta hakim memutus dan mempertimbangkan hanya berdasar bukti dan keterangan para saksi yang diajukan jaksa penuntut umum saja.

2. Saran

a. Bahwa victim precipation seharusnya dijadikan pertimbangan para hakim di Indonesia dalam memutus suatu perkara. Pertimbangan hukum tidka hanya memandang aspek kesalahan pelaku. Keadilan akan 
terwujud apabila

mempertimbangan mengenai aspek kesalahan pelaku maupun korban.

b. Bahwa hakim dalam memutus perkara haruslah memberikan putusan yang seadil-adilnya sehingga Hakim harus menggali keadilan tersebut sebagai pertimbangan yang objektif, jujur, imparsial dan rasional (logis). Dalam hal ini keadilan bukan hanya adil secara formill (Procedural Justice) tetapi juga adil secara materill (Substansive justice) , sehingga diharapkan adanya keadilan yang dianggap ideal bagi pihak pelaku maupun korban.

\section{DAFTAR PUSTAKA}

Angkasa. 2017. Teori Viktimologi dalam kontek Tujuan Viktimologi. Simposium Revitalisasi Hukum Nasional dan Pelatihan Hukum Pidana dan Kriminologi ke-IV, Kupang.

Angkasa dan Iswanto. 2010. Viktimologi. Purwokerto: Universitas Jendral Soedirman.

Bambang Waluyo. 2012. Viktimologi Perlindungan Korban dan Saksi. Jakarta: Penerbit Sinar Grafika.

Dwidja Priyatno. 2009. Sistem Pelaksanaan Pidana Penjara di Indonesia. Bnadung: Penerbit Refika Aditama.

Didik M. Arief Mansur dan Elisatri Gultom. 2008. Urgensi Perlindungan Korban Kejahatan antara Norma dan Realita. Jakarta: Raja Grafindo.

Leden Marpaung. 2009. Asas-teori-Praktek Hukum Pidana. Jakarta: Sinar Grafika.

Lilik Mulyadi. 2007. Kapita Selekta Hukum Pidana Kriminologi dan Viktimologi. Denpasar: Djambatan.

Maya Indah S. 2014. Perlindungan Korban Suatu Perspektif Viktimologi dan
Kriminologi. Jakarta: Penerbit Kencana Prenadamedia Group.

Oksidelfa Yanto. 2010. Mafia Hukum Membongkar Konspirasi dan Manipulasi Hukum di Indonesia. Jakarta: Penebar Swadaya Group.

Peter Mahmud Marzuki. Penelitian Hukum, EdisiRevisi. Jakarta: Kencana Prenadamedia.

Ronny H. Soemitro. 1992. Metodologi Penelitia Hukum. Jakarta: Grahalia ssIndonesia.

Rena Yulia. 2013. Viktimologi Perlindungan Hukum terhadap Korban Kejahatan. Yogyakarta: Graha ilmu.

Sudikno Mertokusumo. 2010. Mengenal Hukum. Yogyakarta: Penerbit Cahaya Atma Pustaka.

Soerjono Sukanto. 2010. Pengantar Peneliti Hukum. Jakarta: UII Pres.

-----. 1986. Penelitian Hukum. Jakarta: Universitas Indonesia.

Sumadi Surya Brata. 1992. Metode Penelitian. Jakarta: Rajawali Press.

Sugiyono. 2008. Memahami Penelitian Kualitatif. Bandung: Alfabet. 